\title{
Proliferation of vesicular stomatitis virus in leucocytes from rheumatoid patients
}

\author{
BRACHA ZISMAN, G. LOEWI, AND J. DORLING \\ From the Divisions of Cell Pathology and Immunology, MRC Clinical Research Centre, Watford Road, Harrow, \\ Middlesex HA1 3 UJ and the MRC Rheumatism Unit, Canadian Red Cross Memorial Hospital, Taplow, \\ Maidenhead, Berkshire
}

In the course of the manifold and persistent searches for an aetiological agent in rheumatoid arthritis (RA) it has been reported that cultured synovial cells from patients suffering from RA fail to be infected by a strain of rubella virus or by Newcastle disease virus (Smith and Hamerman, 1969; Grayzel and Beck, 1970); this was taken as evidence for a pre-existent occult virus infection of the cells. Although this finding has failed to receive confirmation by other investigators (Phillips, 1971; Runge and Allison, 1972) we considered it to be of sufficient significance to examine leucocytes both from the peripheral blood and from joint effusions in RA for their ability to support the growth of vesicular stomatitis virus (VSV); this virus was selected since it is known to replicate in leucocytes (Edelman and Wheelock, 1966). In blood mononuclear leucocytes, we have confirmed replication of VSV when stimulated with either phytohaemagglutinin (PHA) or with pokeweed mitogen (PWM); the leucocytes of RA subjects supported viral replication as well as those of normal donors. VSV also multiplied in association with joint effusion mononuclear cells, although titres were lower than those obtained with stimulated blood leucocytes.

\section{Material and methods}

\section{Leucocytes}

Venous blood was obtained with preservative-free Heparin $(25 \mathrm{u} . / \mathrm{ml}$.) as anticoagulant. Sedimentation of erythrocytes was speeded by the addition of an equal volume of Plasmagel (Bellon, France). Supernatant plasma containing leucocytes was layered on a mixture of Ficoll (Pharmacia) and Triosyl (Glaxo), in accordance with the method of Harris and Ukaejiofo (1969) and centrifuged at 3000 r.p.m. for $20 \mathrm{~min}$. The cellular layer at the interphase between Ficoll and plasma was removed, tissue culture medium Parker 199 (TC 199) was added, and the leucocytes were obtained by centrifugation, followed by washing in TC 199. The cells were found to be mononuclear, with $<1$ per cent. polymorph contamination.

\section{Joint fluids}

These were obtained from the knees of RA patients. $50 \mathrm{u}$. Heparin $/ \mathrm{ml}$. was added. Fluids were incubated for $20 \mathrm{~min}$. at $37^{\circ} \mathrm{C}$. with hyaluronidase (Hyalase, Fison's) to reduce viscosity. Fibrin and tissue fragments were removed by filtration through gauze. TC 199 was added and cells obtained by centrifugation, after one wash in TC 199. Polymorphs were separated from mononuclear cells as described above for blood leucocytes. In the case of joint fluid cells, however, where polymorphs often constitute more than 90 per cent. of the total, separation was frequently incomplete, with up to 30 per cent. polymorph contamination. The mononuclear cells consisted of a mixture of small and medium-sized lymphocytes, probable monocytes, and larger cells probably of synovial membrane origin.

Both blood and joint mononuclear cells were suspended in RPMI medium, 10 per cent. foetal calf serum, Lglutamine, and Hepes buffer.

Cells were cultured in plastic vials containing $10^{6}$ mononuclear cells $/ \mathrm{ml}$. at $37^{\circ} \mathrm{C}$. Phytohaemagglutinin (PHA) was added at $5 \mu \mathrm{l} . / 1 \mathrm{ml}$. culture. Poke-weed mitogen (PWM) (Grand Island Biological Corporation) was added at $50 \mu \mathrm{l} / 1 \mathrm{ml}$. culture. DNA synthesis was assayed by the addition of ${ }^{14} \mathrm{C}$-thymidine (Radiochemical Centre, Amersham, England) $0.08 \mu \mathrm{Ci} /$ culture on the $3 \mathrm{rd}$ day. Cultures so labelled were harvested on Day 4 by washing the cells three times in isotonic saline, followed by application of aliquots to filter paper discs. These were dried, treated with trichloracetic acid followed by dehydration and, after immersion in scintillation fluid, counted in duplicate in a $\beta$-scintillation counter.

\section{Vesicular stomatitis virus (VSV, New Jersey strain)}

Virus stocks were grown in primary chick embryo fibroblast cultures. Supernatant fluids of VSV infected cultures were rapidly frozen and stored at $-70^{\circ} \mathrm{C}$.

Lymphocyte cultures were infected with VSV 24 hrs after initiation. They were centrifuged, and the supernatant was removed and replaced by $0 \cdot 1 \mathrm{ml}$. TC 199 containing $10^{5}$ plaque-forming units (PFU) of VSV.

After $1 \mathrm{hr}$ at $37^{\circ} \mathrm{C}$., TC 199 was added to $2 \mathrm{ml}$, and after centrifugation the cells were washed twice. Finally $1 \mathrm{ml}$. of 
the growth medium was added and the cultures further incubated at $37^{\circ} \mathrm{C}$. Duplicate cultures were terminated immediately after infection and washing, and at 24-hr intervals thereafter by freezing at $-70^{\circ} \mathrm{C}$. for subsequent virus assay.

\section{Titration of VSV}

VSV was assayed by the micro-neutralization technique (DeMadrid and Porterfield, 1969). L-cell monolayers were grown in the wells of WHO haemagglutination trays and infected with $0.1 \mathrm{ml}$. of several 10 -fold dilutions of each sample. After $1 \mathrm{hr}$ 's adsorption at $37^{\circ} \mathrm{C}$., the plates were overlaid with 0.75 per cent. carboxymethylcellulose (low viscosity, B.D.H., Poole, England) in L-15 medium with added 10 per cent. tryptose phosphate broth, 1 per cent. L-glutamine, and 3 per cent. foetal calf serum. After $48 \mathrm{hrs}$ ' incubation at $37^{\circ} \mathrm{C}$., the trays were stained with crystal violet and plaques were counted. Virus titre were expressed in plaque-forming units (p.f.u.) per $0.1 \mathrm{ml}$. cultured fluid.

\section{Electron microscopy}

Cultures of cells infected with VSV were fixed in cold glutaraldehyde. This was followed by post-fixation in $\mathrm{O}_{3} \mathrm{O}_{4}$ and embedding in Epoxy-resin. Sections were cut at $600 \AA$.

\section{Results}

VSV replication, as measured by p.f.u., is shown in Fig. 1. One sample of WBC from a RA patient, one of joint cells, and virus inactivation in the absence of cells are depicted. In effusion cells, stimulated by PHA, viral replication occurred, but to a much smaller extent than in association with WBC. Three normal WBC samples and three RA WBC samples showed similar VSV titres, while cells from four RA joint effusions also supported viral replication, but to a much smaller extent than cells from blood. In all cases, VSV titres were higher when PHA had been

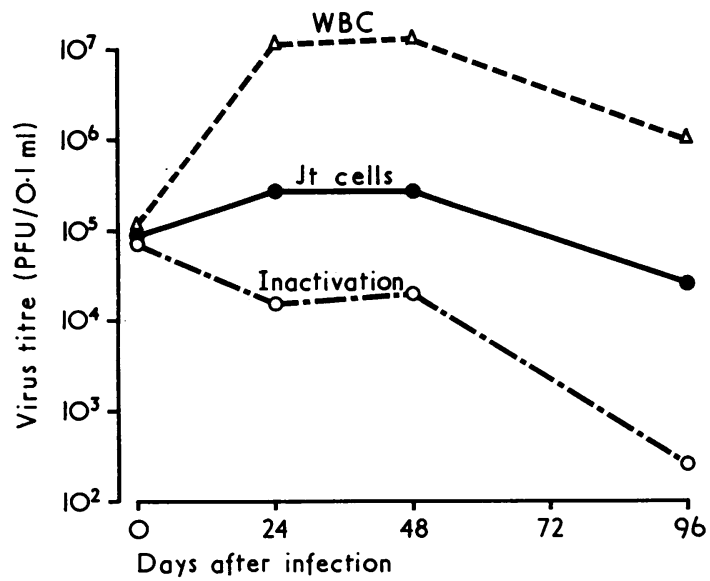

FIG. 1 Replication of VSV in blood and joint effusion leucocytes.

$\Delta=$ Titres in blood mononuclear leucocytes;

- Titres in joint effusion mononuclear cells;

$\mathrm{O}=$ Virus inactivation in the absence of cells added. Maximal titres with WBC were $10^{7}$ to $2 \times 10^{7}$ at 24 or $48 \mathrm{hrs}$ after VSV infection. Joint cells gave the highest titre of $2 \times 10^{6}$ at 72 hrs. Addition of PHA gave increased VSV replication but this effect was much less conspicuous than with WBC. Assessed by $\mathrm{C}^{\mathbf{1 4}}$ thymidine incorporation, average PHA response by joint effusion cells was only approximately 10 per cent. of that given by WBC from RA or normal subjects, with considerable variation between effusions. In two experiments, PWM was compared with PHA as stimulant for WBC. Titres of VSV replication were found to be similar with the two mitogens. When $\mathrm{C}^{14}$ thymidine uptake by PHA or PWM-stimulated WBC was compared with and without VSV infection, it was found that VSV lowered the response by a factor of approximately 6 .

Electron microscopy of cells infected 24 or $48 \mathrm{hrs}$ earlier showed VSV at and apparently within the cell surface (Fig. 2). Only a small number of cells unequivocally showed the presence of VSV. It was hoped to determine the cell type associated with virus replication; owing to the small number of infected cells seen, it is only permissible to state that those cells seen showed lymphoid rather than macrophage characteristics, they contained few intracytoplasmic vesicles, large numbers of ribosomes, and a high nucleus: cytoplasm ratio.

\section{Discussion}

Hamerman (1971) has summarized the evidence for the presence of virus in rheumatoid synovial cells. Resistance to infection by Newcastle disease virus (Smith and Hamerman, 1969) and rubella (Grayzel and Beck, 1970) was taken to indicate the presence of a pre-existing 'virus' in synovial cells in tissue culture. It also appeared that such resistance of rheumatoid cells could be transferred to rabbit cells, growing in tissue culture. Further evidence along this line was obtained by injecting rheumatoid synovial cells into rabbit joints; upon subsequent culture of the rabbit synovial cells, these were also found to be resistant to infection with these viruses.

Since the cells of joint effusions should be in a favourable position to pick up an infection which exists in the cells of the synovium, we considered that they should be tested for their ability to resist further infection in vitro. VSV was chosen since its ability to infect blood mononuclear cells, especially after PHA stimulation has been extensively studied by Edelman and Wheelock $(1966,1967)$. We found that both peripheral blood and effusion mononuclear cells could be successfully infected with VSV, and would therefore question any pre-existing viral infection of these cells. Evidence exists, however, that in some cases herpes virus-infected peritoneal macrophages can be successfully superinfected with sendai virus (Hirsch, Zisman, and Allison, 1970). 


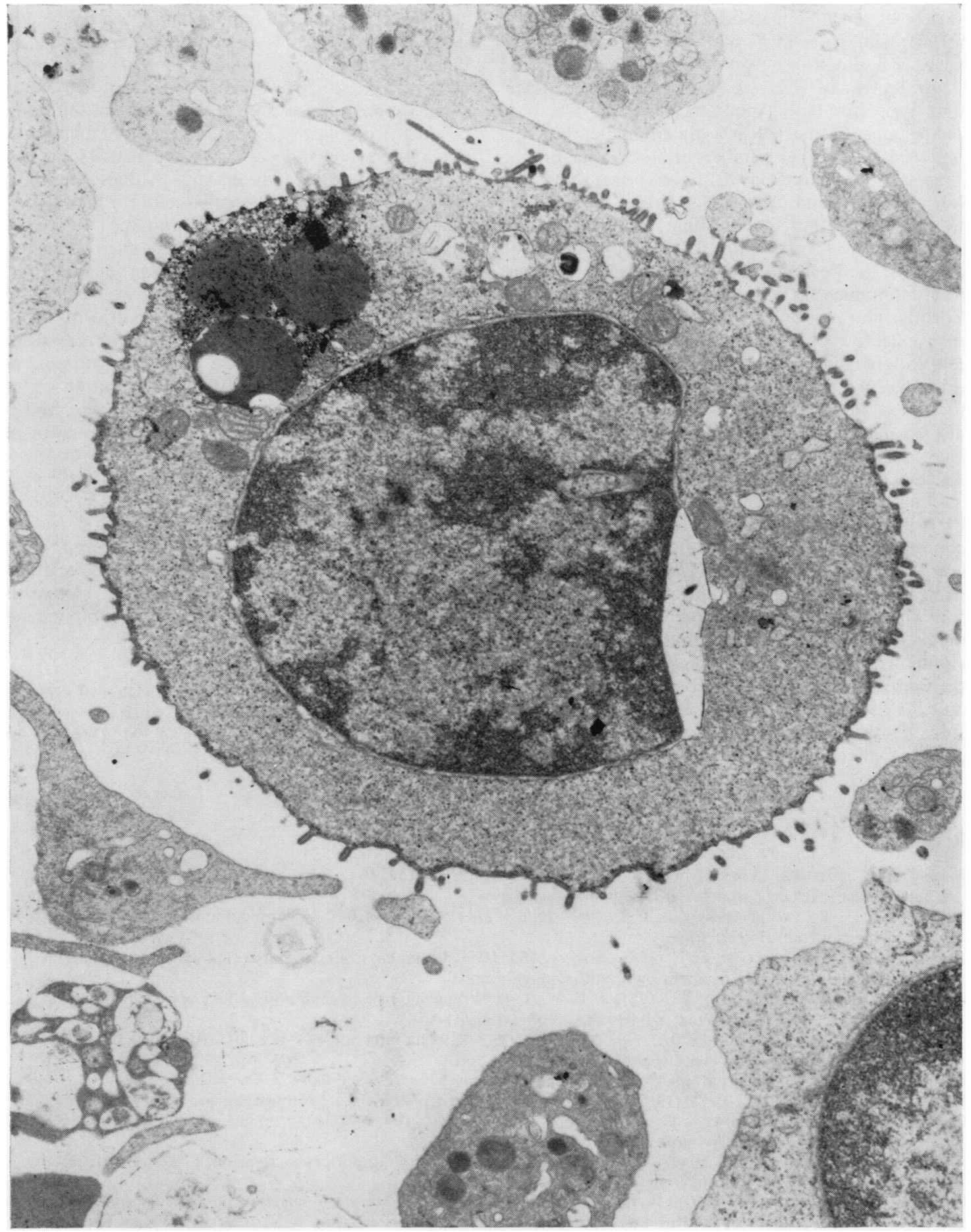

FIG. 2 Electron micrograph of blood mononuclear cells infected with VSV. Culture stimulated with PHA, and infected with VSV for 24 hrs. Virus is seen at the cell surface. $\times 24,000$ 
It should be added that Phillips (1971), using a variety of sensitive methods, failed to find evidence for viral infection in a total of 187 synovial specimens, including those from RA and controls.

Viral titres of infected effusion cells were lower than those for blood mononuclear cells. The blast cell response of joint cells was much smaller than that obtained with similar numbers of blood cells. Bloom, Jimenez, and Marcus (1970) have shown that replication of VSV and other RNA viruses is supported by activated rather than resting lymphocytes, thus suggesting an explanation for this difference. In addition, the percentage of lymphoid cells amongst joint mononuclears is smaller than that in the blood. Edelman and Wheelock (1967) have adduced evidence to implicate monocytes as the host cells for virus replication, but their method of separation was probably not entirely satisfactory, since it is likely to have separated part of the lymphocyte population at the same time. Their own finding of the enhancement of virus replication by PHA stimulation suggests a lymphocyte as the host cell.

In addition to enhancement of VSV replication by PHA stimulation, we have found PWM to have a comparable effect. It is generally assumed that PHA is a T-cell stimulant for human as it is for murine cells, while the type of cell susceptible to PWM stimulation is unknown in the case of human leucocytes; in the mouse, there is evidence that both $\mathrm{T}$ and $\mathrm{B}$ cells are stimulated by PWM (Janossy and Greaves, 1972). In the present experiments, the levels of blast response and VSV replication by blood mononuclears were similar with PHA and PWM, while joint effusion cells gave a smaller response with either mitogen.
Bloom and others (1970) stimulated lymph node cells from immunized guinea-pigs with PPD and infected such cultures with VSV. The number of plaques formed was dependent on PPD stimulation of sensitive cells. From the lack of effect or the only slight suppression of VSV replication on addition of colchicine, vinblastine, or large amounts of thymidine, the authors concluded that in the first $\mathbf{4 8} \mathrm{hrs}$ the increases in antigen-induced viral plaques essentially represent initial antigen-reactive cells. It is most likely that these were lymphocytes. Our attempt to identify the virus-susceptible cells by electron microscopy has enabled us to visualize some virus-producing cells. These appear to be lymphocytes, but we have found too few for a definite conclusion to be drawn.

Lastly, VSV replication was in all cultures associated with marked decrease of DNA synthesis, as measured by $\mathrm{C}^{14}$ thymidine incorporation. This again suggests involvement of a lymphocyte, and is presumed to be the result of a cytopathic effect of VSV.

\section{Summary}

Mononuclear leucocytes from blood and joint effusions of patients with rheumatoid arthritis supported the replication of vesicular stomatitis virus. This was increased by mitogens. Lymphocytes are considered to be the host cells.

We thank Dr. M. Gumpel for the provision of synovial fluids and Miss J. Snajdr and Mr. J. Willcox for technical assistance. We are grateful to Dr. A. M. Denman for valuable discussion.

\section{References}

Bloom, B. R., Jimenez, L., ANd Marcus, P. I. (1970) J. exp. Med., 132, 16 (A plaque assay for enumerating antigen-sensitive cells in delayed-type hypersensitivity)

De Madrid, A. T., AND Porterfield, J. S. (1969) Bull. Wld Hlth Org., 40, 113 (A simple micro-culture method for the study or group $B$ arboviruses)

Edelman, R., AND WHEelock, E. F. (1966) Science, 154, 1053 (Vesicular stomatitis virus replication in human leukocyte cultures: enhancement by phytohaemagglutinin)

Edelman, R., AND WheELOCK, E. F. (1967) J. Virol., 1, 1139 (Specific role of each human leukocyte type in viral infections. 1. Monocyte as host cell for VSV replication in vitro)

Grayzel, A. I., AND BECK, C. (1970) J. exp. Med., 131, 367 (Rubella infection of synovial cells and the resistance of cells derived from patients with rheumatoid arthritis)

Hamerman, D. (1971) 'Rheumatoid Arthritis' Academic Press, New York, p. 489

HARRIS, R., AND UKAEJIOFO, E. O. (1969) Lancet, 2, 367 (Rapid preparation of lymphocytes for tissue-typing)

Hirsch, M. S., Zisman, B., AND Allison, A. C. (1970) J. Immunol., 104, 1160 (Macrophages and age-dependent resistance to herpes simplex virus in mice)

Janossy, G., AND Greaves, M. F. (1971) Clin. exp. Immunol., 9, 483 (Lymphocyte activation. I. Response of T and B lymphocytes to phytomitogens)

Phillips, P. E. (1971) J. exp. Med., 134, no. 3, pt. 2, p. 313s (Virologic studies in rheumatoid arthritis and other connective tissue diseases in "Immune Complexes and Disease: Proc. Symp. N.Y. Heart Ass., New York, 1971")

Runge, L. A., AND Allison, A. C. (1972) Arthr. and Rheum., 15, 85 (Growth of rubella virus in cultures of synovial cells from rheumatoid arthritis)

Smith, C., AND Hamerman, D. (1969) Ibid., 12, 639 (Significance of persistent differences between normal and rheumatoid synovial membrane cells in culture) 